\title{
VERTICAL TRANSMISSION OF HUMAN IMMUNODEFICIENCY VIRUS
}

\author{
(A REVIEW)* \\ FEREnC D. Tóth, AtTIla BÁcsi, ZoltÁn Beck AND Judit SzABÓ \\ Institute of Microbiology, Medical and Health Science Center, University of Debrecen, \\ Nagyerdei krt. 98, H-4012 Debrecen, Hungary
}

(Received: April 2, 2001; accepted: April 17, 2001)

\begin{abstract}
Sensitive detection methods, such as DNA PCR and RNA PCR suggest that vertical transmission of human immunodeficiency virus (HIV) occurs at three major time periods; in utero, around the time of birth, and postpartum as a result of breastfeeding (Fig. 1). Detection of proviral DNA in infant's blood at birth suggests that transmission occurred prior to delivery. A working definition for time of infection is that HIV detection by DNA PCR in the first $48 \mathrm{~h}$ of life indicates in utero transmission, while peripartum transmission is considered if DNA PCR is negative the first $48 \mathrm{~h}$, but then it is positive 7 or more days later [1]. Generally, in the breastfeeding population, breast milk transmission is thought to occur if virus is not detected by PCR at 3-5 months of life but is detected thereafter within the breastfeeding period [2]. Using these definitions and guidelines, studies has suggested that in developed countries the majority, or two thirds of vertical transmission occur peripartum, and one-third in utero [3-6]. The low rate of breastfeeding transmission is due to the practice of advising known HIV-positive mothers not to feed breast milk. However, since the implementation of antiretroviral treatment in prophylaxis of HIV-positive mothers, some studies have suggested that in utero infection accounts for a larger percentage of vertical transmissions [7]. In developing countries, although the majority of infections occurs also peripartum, a significant percentage, $10-17 \%$, is thought to be due to breastfeeding $[2,8,9]$.
\end{abstract}

Keywords: HIV, vertical transmission, routes of infection

* This paper was written to commemorate to the fiftieth anniversary of the foundation of the Hungarian Society for Microbiology. 
Fig. 1. Timing of vertical HIV infection: estimate of percent attributable to in utero, peripartum and postpartum (breast feeding) transmission

\section{Transplacental transmission of HIV}

Syncytiotrophoblast forms a continuous, multinucleated epithelium (Fig. 2) that must be traversed by HIV in order to reach underlying cytotrophoblast cells, placental macrophages, fibroblasts, and endothelial cells lining the fetal capillaries. Transmission through the placenta could involve (I) direct transmission of infected cells (monocytes or $T$ cells) from the mother through lesions of the placental barrier, (II) transcytosis, i.e. transport across the trophoblast layer of infected cells, (III) infection of trophoblasts, (IV) entry of the virus in the form of virus/maternal antibody complex.

\section{HIV infection of syncytiotrophoblast}

Direct evidence of the infection of syncytiotrophoblast was described. Using immunocytochemical and in situ hybridization techniques, researchers detected HIV antigens and genetic material in trophoblast samples obtained from HIV-infected women [10-13].

The problem of the infection of syncytiotrophoblast cells remains controversial. Even if HIV has been detected in the syncytiotrophoblast layer in situ [10-12], in vitro studies are more conflicting. Several studies demonstrated that cultured human 
trophoblasts are moderately, but effectively, susceptible to infection by laboratory strains of HIV [14-16]. In contrast, other investigators have been unable to demonstrate any trophoblast infection with cell-free virus $[17,18]$ and claim that cellcell contact is an absolute requirement for HIV infection of syncytiotrophoblast cells.

Fig. 2. Human syncytiotrophoblast in culture

The conflicting results may be due to several experimental variables, such as differences in HIV isolates used for infection of syncytiotrophoblast cells or the use of different detection assays. Fazely et al. [19] demonstrated that placental syncytiotrophoblast cells can be infected with cell-free HIV, but cell-associated infection of syncytiotrophoblasts is more efficient than the infection with cell-free virus. Viral particles were observed in coated pits at the syncytiotrophoblast cell surface. This observation is consistent with an endocytosis-mediated mechanism of virus entry. Results from a recent study [20] suggest that cell-free HIV can enter syncytiotrophoblasts and the susceptibility of these cells to penetration by the virus is strain dependent. Furthermore, infectious HIV strains do not require cell surface CD4 
or chemokine receptors to gain entry into syncytiotrophoblast cells. Other reports of the infection of human syncytiotrophoblast culture with cell-free HIV indicate that, at best, only low level of productive viral replication is achieved $[14,15]$. The lack of virus production in syncytiotrophoblast cells after in vitro contact with cell-free HIV indicate post entry restriction of replication. It is conceivable, however, that productive infection of trophoblast in vivo might occur in defined, transient conditions. Observations in support of this assumption include detection of HIV p24 antigen in the placental trophoblastic cells of HIV-positive gravidae $[10,12]$. These findings suggest that multiple cofactors are likely to be involved in the transplacental transmission of the virus. The stimulatory effect of tumor necrosis factor- $\alpha$ on HIV gene expression in syncytiotrophoblast cells has been demonstrated [21]. Another possible mechanism for the stimulation of HIV replication may be co-infection with other viruses. A good candidate for this scenario is human cytomegalovirus [16]. The syncytiotrophoblasts as an overlapping cell population can be coinfected with HIV and human cytomegalovirus, and HIV replication is markedly upregulated by previous or simultaneous infection of the cells with cytomegalovirus (Fig. 3).

The phenomenon of antibody-dependent enhancement of virus infection is another means by which HIV can enter cells. In this scheme, virus is internalized as an immune complex via interaction with cell surface $\mathrm{Fc}$ receptors or with complement receptors. Antibody-dependent enhancement of HIV binding and infection of certain cells were demonstrated in vitro [22, 23]. Human syncytiotrophoblast plasma membrane expresses $\mathrm{Fc}$ receptors, and these receptors may function in maternal-fetal transmission of immunoglobulin [24]. Immunohistochemical studies suggest that syncytiotrophoblast has low numbers of CR2-like complement receptors [25, 26]. HIV infection of human trophoblast cells in the presence of HIV antibody-positive serum was first reported by David et al. [27]. In an other study [28] it has been shown that both Fc receptor-mediated and complement-mediated antibody-dependent enhancement can contribute to the uptake of HIV/antibody complexes by syncytiotrophoblast cells and that $\mathrm{Fc}$ receptor-mediated antibody-dependent enhancement is more efficient than complement-mediated antibody-dependent enhancement (Figs 4 and 5).

\section{Anchoring villi and chorioamnion}

While it is generally assumed that maternal-fetal transmission of HIV would be achieved across the syncytiotrophoblast of free placental villi, two other possible routes of infection warrant consideration.

One possible route involves the anchoring villi. As the placenta develops, specialized structures known as anchoring villi and cell columns are formed at the junction of fetal and maternal tissue [29]. Their unusual organization affords a potential 
pathway for viral entry into fetal tissues that does not involve passage of virus across syncytiotrophoblast. HIV could pass from uterine cells and stroma, go between cytotrophoblastic cells of the cell columns, and enter fetal stroma. The cytotrophoblastic cells are joined by desmosomes but lack tight junctions.

Fig. 3. Effect of HCMV infection on HIV-1 production. Syncytiotrophoblast cells were infected with HIV-1 alone ( ), HCMV and HIV-1 simultaneously ( $\mathrm{O}$ ), HCMV for 1 day and then HIV-1 $(\Delta)$, or HCMV for 4 days and then HIV-1 $(\square)$. The amount of HIV-1 was determined by syncytium-forming assay

Another potential route of HIV infection of the fetus is across the chorioamnion. Here, in late gestation cellular trophoblast abuts on maternal decidua. The decidua contains maternal blood vessels, macrophages and lymphocytes and thus may serve to expose the adjacent trophoblast to HIV. From here, virus or cells may cross the fetal connective tissue and amnion and enter the amniotic fluid. HIV has been isolated from amniotic fluid and cells, but the pathway by which virus enters the fluid is unknown [30]. 
Fig. 4. Fc receptor-mediated antibody-dependent enhancement of HIV-1 infection in syncytiotrophoblast cells. Cell were infected by HIV-1 alone $(\bullet)$ or in the presence of infection enhancing antibodies (

\section{Selection of maternal HIV variants in human placenta}

Several findings suggest that the placenta acts as a very effective barrier against HIV infection. The virus populations detected in chorionic villi, particularly in the trophoblast cells, are much more homogeneous than are those detected in maternal peripheral blood mononuclear cells throughout the pregnancy [31, 32]. These data indicate that trophoblastic cells may also be involved in the selective process. Placental cell populations other than trophoblastic cells may also be involved in selection of HIV within the placenta. According to some reports, viruses with macrophage tropism are transmitted preferentially during pregnancy [33, 34].

The role of Hofbauer cells, macrophages believed to be of fetal origin and present in the mesenchymal core of the chorionic villi [35], is also of interest in viral pathogenesis. They are present in the villi prior to the development of bone marrow. They maintain their ability to undergo mitosis and self-replicate, in contrast to bone marrow-derived macrophages. In situ PCR revealed the presence of HIV proviral DNA in Hofbauer cells in placentas of HIV-infected mothers [10,36]. Hofbauer cells support infection and replication of HIV and do not show the cytopathic effect of infection even when measurable infection has occurred [37]. Transport of HIV across the syncytiotrophoblast barrier would be particularly efficient in delivery of the virus to its 
first target cells, since placental macrophages lay immediately under the trophoblast layer [38].

Fig. 5. Complement-mediated antibody-dependent enhancement of HIV-1 infection in syncytiotrophoblast cells. Cells were infected by HIV-1 alone $(\mathbf{O})$ or in the presence of infection enhancing antibodies $(\boldsymbol{\Delta})$ plus complement

The villous macrophages are likely candidates for infection by the virus. Similar to other phagocytic cells, Hofbauer cells are probably motile, and they occur in sufficient numbers to permit the transfer of HIV to other cells. Endothelial cells, lining placental blood vessels may also become infected with the virus.

It is conceivable that the spread and selection of maternal virus variants within the placenta results from a cascade of infection of distinct placental cell populations. Altogether, maternal HIV variants appear to undergo a strong negative selection by different cell populations within the placental villi. This may explain why the transplacental transmission of HIV is less frequent than it would be anticipated by the detection of proviral DNA in $70 \%$ of placentas from HIV-infected women [6, 39]. 


\section{Intrapartum infection}

During labor and vaginal delivery there is direct contact with maternal genital secretions and blood associated with labor and with passage through the birth canal. Cervicovaginal secretions contain both free and cell-associated virus [40]. With prolonged rupture of membranes there is increased risk of an ascending infection from the vagina or cervix to the fetal membranes and amniotic cavity. Uterine contractions also result in maternal-fetal micro-transfusions. In normal deliveries, maternofetal transfusion of approximately $3 \mathrm{ml}$ occurs. This transfusion is attributed to uterine contractions and villous changes associated with maturation, which may have some importance in vertical transfer of HIV. As few as one maternal cell among 100,000 fetal cells can be detected in cord blood [41]. Transfusion is less expressed in scheduled elective caesarian sections and following short labors of less than $5 \mathrm{~h}$ and it is greater in prolonged labor [42].

\section{Breastfeeding}

Breastfeeding is an important HIV risk factor, particularly in developing countries. Colostrum and breast milk have been shown to contain virus [43]. Infant infection through breastfeeding is thought to occur in $14 \%$ of chronically infected women and in $29 \%$ with acute infection [8]. Increasing viral load (by DNA PCR) with time has been detected in breast milk postpartum [44]. This is consistent with the findings that the risk for breast milk transmission appears to increase with duration of breastfeeding [8, 45]. Furthermore, the increased risk seems to be significant 4-6 months postpartum, suggesting that if these findings are verified it may be appropriate to recommend that in some developing countries HIV-positive mothers could breast feed infants until 3 months of age.

\section{Factors associated with transmission}

Multiple maternal characteristics have been associated with increased risk of mother-to-child transmission. These characteristics can be loosely categorized as virologic and immunological cofactors (Table I). 
Table I

Factors associated with vertical transmission of HIV

\begin{tabular}{ll}
\hline & \multicolumn{1}{c}{ Factors } \\
\hline \multirow{2}{*}{ Virologic } & HIV culture positivity during pregnancy \\
& Plasma HIV RNA load \\
& HIV phenotype \\
& Co-infecting viruses: HCV, HCMV \\
& \\
\hline Immunological & CD4+ cell count \\
& ADCC \\
& CTL response \\
\hline
\end{tabular}

\section{Virologic factors}

Persistent HIV culture positivity during pregnancy and higher levels of infectious virus determined by quantitative culture have been associated with increased risk of transmission [46]. Viral load, which is related to clinical and immunological status in the mother, is the main contributing factor for HIV vertical transmission. Higher maternal plasma HIV RNA level has been associated with increased risk, but a threshold by which transmission will likely occur has not been defined consistently and clearly [47, 48]. Although both T-cell-tropic and macrophage-tropic viral sequences can be found in the placental tissue [49], viruses with macrophage tropism are transmitted preferentially during pregnancy $[33,34]$. These data indicate that Hofbauer cells may be involved in selection of maternal HIV variants within the placenta.

Associated viral infections could also act as cofactors. Early studies in Italy showed that women infected with hepatitis $\mathrm{C}$ virus and HIV had a higher transmission rate [50]. Increased HIV vertical transmission associated with maternal hepatitis $\mathrm{C}$ virus infection has also been demonstrated in a recent study [51]. Maternal immune status has a major effect on the incidence of congenital infections. Prior maternal immunity to human cytomegalovirus protects the fetus from intrauterine infection. HIV-infected women are likely to be at high risk to transmit cytomegalovirus to their infants, regardless of whether they have primary or recurrent cytomegalovirus infection during pregnancy. Women with both HIV and cytomegalovirus infection may have decreased immune function and increased viraemia when compared to women infected with HIV alone. The incidence of cytomegalovirus infection in congenitally HIVinfected children is $61 \%$, whereas it is only $8 \%$ in HIV seroconverters [52]. It has been shown that congenital cytomegalovirus infection is more common in HIV-infected 
infants than in HIV-uninfected infants [53]. Analysis of the patterns of HIV and cytomegalovirus replication in singly and dually infected syncytiotrophoblast cells has shown that replication of HIV is markedly upregulated by previous or simultaneous infection of the cells with cytomegalovirus. On the other hand, prior HIV infection of the cells converts cytomegalovirus infection from a nonpermissive state to a permissive one. These data suggest that interactions between HIV and cytomegalovirus in coinfected syncytiotrophoblast cells may contribute to the transplacental transmission of both viruses [16]. Another potential mechanism for increased cytomegalovirus transmission in HIV-infected pregnant women would result from increased recruitment of HIV-infected macrophages in the presence of cytomegalovirus endocervicitis [54]. The presence of these macrophages could increase the risk of perinatal transmission. Infection with cytomegalovirus in HIV-positive children is an unfavorable prognostic factor for the outcome of HIV disease $[55,56]$.

\section{Immunological factors}

The immunological status of the HIV-infected mothers has also been evaluated. Low maternal CD4+ lymphocyte counts has been linked to higher transmission risk in several studies [57, 58]. Recent studies also demonstrated the importance of activated CD8 cell markers as a sign of viraemia in transmission and their similar interaction with positive culture status [46, 59].

In the infant, although theoretically antibody-dependent cellular cytotoxicity (ADCC) activity could be an important defense against HIV infection, in a limited mother-infant study, generation of ADCC was shown to be delayed in newborns and was not associated with decreased risk [60]. However, HIV-specific cytotoxic $\mathrm{T}$ lymphocytes (CTL) have been detected in uninfected infants born to HIV-positive mothers, suggesting that an appropriate host CTL response could be protective against infection [61].

\section{Conclusions}

Despite the changing epidemiology of HIV vertical transmission in developed countries due to the relative acceptance and success of maternal and infant antiretroviral therapy as prophylaxis, mother-to-infant transmission continues to cause unacceptable morbidity and mortality in both developing and developed countries. To further decrease transmission rates worldwide, a continuing challenge is necessary to better understand the pathogenesis of HIV vertical transmission. 


\section{References}

1. Bryson, Y.J., Luzuriaga,K., Sullivan, J.L., Wara, D.W.: Proposed definitions for in utero versus intrapartum transmission of HIV-1. N Engl J Med 327, 1246 (1992)

2. Bertolli, J., St. Louis, M.E., Simonds, R.J.; Nieburg, P., Kamenga, M., Brown, C., Tarande, M., Quinn, T., Ou, C.Y.: Estimating the timing of mother-to-child transmission of human immunodeficiency virus in a breast-feeding population in Kinshasa, Zaire. J Infect Dis 174, 722 (1996)

3. Dunn, D.T., Brandt, C.D., Krivine, A., Cassol, S.A., Roques, P., Borkowsky, W., De Rossi, A., Denamur, E., Ehrnst, A., Loveday, C.: The sensitivity of HIV-1 DNA polymerase chain reaction in the neonatal period and the relative contributions of intra-uterine and intra-partum transmission. AIDS 9, F7 (1995)

4. Rouzioux, C., Costagliola, D., Burgard, M., Blanche, S., Mayaux, M.J., Griscelli, C., Valleron, A.J.: Estimated timing of mother-to-child human immunodeficiency virus type 1 (HIV-1) transmission by use of a Markov model. Am J Epidemiol 142, 1330 (1995)

5. Kalish, L.A., Pitt, J., Lew, J., Landesman, S., Diaz, C., Hershow, R., Hollinger, F.B., Pagano, M., Smeriglio, V., Moye, J.: Defining the time of fetal or perinatal acquisition of human immunodeficiency virus type 1 infection on the basis of age at first positive culture. J Infect Dis 175, 712 (1997)

6. Chouquet, C., Burgard, M., Richardson, S., Rouzioux, C., Costagliola, D.: Timing of mother-to-child HIV-1 transmission and diagnosis of infection based on polymerase chain reaction in the neonatal period by a non-parametric method. AIDS 11, 1183 (1997)

7. Dickover, R.E., Garratty, E.M., Herman, S.A., Sim, M.S., Plaeger, S., Boyer, P.J., Keller, M., Deveikis, A., Stiehm, E.R., Bryson, Y.J.: Identification of levels of maternal HIV-1 RNA associated with risk of perinatal transmission. Effect of maternal zidovudine treatment on viral load. JAMA 275, 599 (1996)

8. Dunn, D.T., Newell, M.L., Ades, A.E., Peckham, C.S.: Risk of human immunodeficiency virus type 1 transmission through breastfeeding. Lancet 340, 585 (1992)

9. Ekpini, E.R., Wiktor, S.Z., Satten, G.A., Adjorlolo-Johnson, G.T., Sibailly, T.S., Ou, C.Y., Karon, J.M., Brattegaard, K., Whitaker, J.P., Gnaore, E., De Cock, K.M., Greenberg, A.E.: Late postnatal mother-tochild transmission of HIV-1 in Abidjan, Cote d'Ivoire. Lancet 349, 1054 (1997)

10. Lewis, S.H., Reynolds-Kohler, C., Fox, H.E., Nelson, J.A.: HIV-1 in trophoblastic and villous Hofbauer cells, and haematological precursors in eight-week fetuses. Lancet. 335, 565 (1990)

11. Chandwani, S., Greco, M.A., Mittal, K., Antoine, C., Krasinski, K., Borkowsky, W.: Pathology and human immunodeficiency virus expression in placentas of seropositive women. J Infect Dis 163, 1134 (1991)

12. Backe, E., Jimenez, E., Unger, M., Schafer, A., Jauniaux, E., Vogel, M.: Demonstration of HIV-1 infected cells in human placenta by in situ hybridisation and immunostaining. J Clin Pathol 45, 871 (1992)

13. Zachar, V., Thomas, R.A., Jones, T., Goustin, A.S.: Vertical transmission of HIV: detection of proviral DNA in placental trophoblast. AIDS 8, 129 (1994)

14. Mano, H., Chermann, J.C.: Replication of human immunodeficiency virus type 1 in primary cultured placental cells. Res Virol 142, 95 (1991)

15. Zachar, V., Norskov-Lauritsen, N., Juhl, C., Spire, B., Chermann, J.C., Ebbesen, P.: Susceptibility of cultured human trophoblasts to infection with human immunodeficiency virus type 1. J Gen Virol 72 , 1253 (1991) 
16. Tóth, F.D., Mosborg-Petersen, P., Kiss, J., Aboagye-Mathiesen, G., Hager, H., Juhl, C.B., Gergely, L., Zdravkovic, M., Aranyosi, J., Lampé, L., Ebbesen, P.: Interactions between human immunodeficiency virus type 1 and human cytomegalovirus in human term syncytiotrophoblast cells coinfected with both viruses. J Virol 69, 2223 (1995)

17. Bourinbaiar, A.S., Nagorny, R.: Human immunodeficiency virus type 1 infection of choriocarcinomaderived trophoblasts. Acta Virol 37, 21 (1993)

18. Kilani, R.T., Chang, L.J., Garcia-Lloret, M.I., Hemmings, D., Winkler-Lowen, B., Guilbert, L.J.: Placental trophoblasts resist infection by multiple human immunodeficiency virus (HIV) type 1 variants even with cytomegalovirus coinfection but support HIV replication after provirus transfection. J Virol 71, 6359 (1997)

19. Fazely, F., Fry, G.N., Thirkill, T.L., Hakim, H., King, B.F., Douglas, G.C.: Kinetics of HIV infection of human placental syncytiotrophoblast cultures: an ultrastructural and immunocytochemical study. AIDS Res Hum Retroviruses 11, 1023 (1995)

20. Bácsi, A., Ebbesen, P., Szabó, J., Beck, Z., Andirkó, I., Csoma, E., Tóth, F.D.: Pseudotypes of vesicular stomatitis virus bearing envelope antigens of certain HIV-1 strains permissively infect human syncytiotrophoblasts cultured in vitro: implications for in vivo infection of syncytiotrophoblasts by cellfree HIV-1. J Med Virol 64:387 (2001).

21. Lee, B.W., Ordonez, N., Popek, E.J., Lu, J.G., Helfgott, A., Eriksen, N., Hammill, H., Kozinetz, C., Doyle, M., Kline, M., Langston, C., Shearer, W.T., Reuben, J.M.: Inflammatory cytokine expression is correlated with the level of human immunodeficiency virus (HIV) transcripts in HIV-infected placental trophoblastic cells. J Virol 71, 3628 (1997)

22. Robinson, W.E., Montefiori, D.C., Mitchell, W.M.: Antibody-dependent enhancement of human immunodeficiency virus type 1 infection. Lancet 331, 790 (1988)

23. Homsy, J., Meyer, M., Tateno, M., Clarkson, S., Levy, J.A.: The Fc and not CD4 receptor mediates antibody enhancement of HIV infection in human cells. Science 244, 1357 (1989)

24. Wild, A.E.: Trophoblast cell surface receptors. In: Loke, Y.W., Whyte, A. (eds) Biology of trophoblast. Amsterdam: Elsevier, 471 (1983)

25. Sinha, D., Wells, M., Faulk, W.P.: Immunological studies of human placentae: complement components in pre-eclamptic chorionic villi. Clin Exp Immunol 56, 175 (1984)

26. Leivo, I., Engvall, E.: C3d fragment of complement interacts with laminin and binds to basement membranes of glomerulus and trophoblast. J Cell Biol 103, 1091 (1986)

27. David, F.J., Autran, B., Tran, H.C., Menu, E., Raphael, M., Debre, P., Hsi, B.L., Wegman, T.G., BarreSinoussi, F., Chaouat, G.: Human trophoblast cells express CD4 and are permissive for productive infection with HIV-1. Clin Exp Immunol 88, 10 (1992)

28. Tóth, F.D., Mosborg-Petersen, P., Kiss, J., Aboagye-Mathiesen, G., Zdravkovic, M., Hager, H., Aranyosi, J., Lampé, L., Ebbesen, P.: Antibody-dependent enhancement of HIV-1 infection in human term syncytiotrophoblast cells cultured in vitro. Clin Exp Immunol 96, 389 (1994)

29. Enders AC.: Fine structure of anchoring villi of the human placenta. Am J Anat 122, 419 (1968)

30. Mundy, D.C., Schinazi, R.F., Gerber, A.R., Nahmias, A.J., Randall, H.W.: Human immunodeficiency virus isolated from amniotic fluid. Lancet II, 459 (1987)

31. Menu, E., Mbopi-Keou, F.X., Lagaye, S., Pissard, S., Mauclere, P., Scarlatti, G., Martin, J., Goossens, M., Chaouat, G., Barre-Sinoussi, F.: Selection of maternal human immunodeficiency virus type 1 variants in human placenta. J Infect Dis 179, 44 (1999) 
32. Zachar, V., Zacharova, V., Fink, T., Thomas, R.A, King, B.R., Ebbesen, P., Jones, T.B., Goustin, A.S.: Genetic analysis reveals ongoing HIV type 1 evolution in infected human placental trophoblast. AIDS Res Hum Retroviruses 15, 1673 (1999)

33. Van't-Wout, A.B., Kootstra, N.A., Mulder-Kampinga, G.A., Albrecht van Lent, N., Scherpbier, H.J., Veenstra, J., Boer, K., Coutinho, R.A., Miedema, F., Schuitemaker, H.: Macrophage-tropic variants initiate human immunodeficiency virus type 1 infection after sexual, parenteral, and vertical transmission. J Clin Invest 94, 2060 (1994)

34. Ometto, L., Zanotto, C., Maccabruni, A., Caselli, D., Truscia, D., Giaquinto, C., Ruga, E., ChiecoBianchi, L., De Rossi, A.: Viral phenotype and host-cell susceptibility to HIV-1 infection as risk factors for mother-to-child HIV-1 transmission. AIDS 9, 427 (1995)

35. Castellucci, M., Celona, A., Bartels, H., Steininger, B., Benedetto, V., Kaufmann, P.: Mitosis of the Hofbauer cell: possible implications for a fetal macrophage. Placenta 8, 65 (1987)

36. Zevallos, E.A., Anderson, V.M., Bard, E.: Detection of HIV-1 sequences in placentas of HIV-infected mothers by in situ PCR. Cell Vision 1, 116 (1994)

37. Kesson, A.M., Fear, W.R., Kazazi, F., Mathijs, J.M., Chang, J., King, N.J., Cunningham, A.L.: Human immunodeficiency virus type 1 infection of human placental macrophages in vitro. J Infect Dis 168, 571 (1993)

38. Goldstein, J., Braverman, M., Salafia, C., Buckley, P.: The phenotype of human placental macrophages and its variation with gestational age. Am J Pathol 133, 648 (1988)

39. De Andreis, C., Simoni, G., Rossella, F., Castagna, C., Pesenti, E., Porta, G., Colucci, G., Giuntelli, S, Pardi, G., Semprini, A.E.: HIV-1 proviral DNA polymerase chain reaction detection in chorionic villi after exclusion of maternal contamination by variable number of tandem repeats analysis. AIDS 10, 711 (1996)

40. Henin, Y., Mandelbrot, L., Henrion, R., Pradinaud, R., Coulaud, J.P., Montagnier, L.: Virus excretion in the cervicovaginal secretions of pregnant and nonpregnant HIV-infected women. J Acquir Immune Defic Syndr 6, 72 (1993)

41. Lo, Y.M., Lo, E.S., Watson, N., Noakes, L., Sargent, I.L., Thilaganathan, B., Wainscoat, J.S.: Two-way cell traffic between mother and fetus: biologic and clinical implications. Blood 88, 4390 (1996)

42. Kaneda, T., Shiraki, K., Hirano K., Nagata, I.: Detection of maternofetal transfusion by placental alkaline phosphatase levels. J Pediatr 130, 730 (1997)

43. Thiry, L., Sprecher-Goldberger, S., Jonckheer, T., Levy, J., Van de Perre, P., Henrivaux, P., CogniauxLeClerc, J., Clumeck, N.: Isolation of AIDS virus from cell-free breast milk of three healthy virus carriers. Lancet II, 891 (1985)

44. Nduati, R.W., John, G.C., Richardson, B.A., Overbaugh, J., Welch, M., Ndinya-Achola, J., Moses, S., Holmes, K., Onyango, F., Kreiss, J.K.: Human immunodeficiency virus type 1-infected cells in breast milk: association with immunosuppression and vitamin A deficiency. J Infect Dis 172, 1461 (1995)

45. Datta, P., Embree, J.E., Kreiss, J.K., Ndinya-Achola, J.O., Braddick, M., Temmerman, M., Nagelkerke, N.J., Maitha, G., Holmes, K.K., Piot, P.: Mother-to-child transmission of human immunodeficiency virus type 1: report from the Nairobi Study. J Infect Dis 170, 1134 (1994)

46. Pitt, J., Brambilla, D., Reichelderfer, P., Landay, A., McIntosh, K., Burns, D., Hillyer, G.V., Mendez, H., Fowler, M.G.: Maternal immunologic and virologic risk factors for infant human immunodeficiency virus type 1 infection: findings from the Women and Infants Transmission Study. J Infect Dis 175, 567 (1997) 
47. Coll, O., Hernandez, M., Boucher, C.A., Fortuny, C., de Tejada, B.M., Canet, Y., Caragol, I., Tijnagel, J., Bertran, J.M., Espanol, T.: Vertical HIV-1 transmission correlates with a high maternal viral load at delivery. J Acquir Immune Defic Syndr Hum Retrovirol 14, 26 (1997)

48. Thea, D.M., Steketee, R.W., Pliner, V., Bornschlegel, K., Brown, T., Orloff, S., Matheson, P.B., Abrams, E.J., Bamji, M., Lambert, G., Schoenbaum, E.A., Thomas, P.A., Heagarty, M., Kalish, M.L.: The effect of maternal viral load on the risk of perinatal transmission of HIV-1. New York City Perinatal HIV Transmission Collaborative Study Group. AIDS 11, 437 (1997)

49. McGann, K.A., Collman, R., Kolson, D.L., Gonzalez-Scarano, F., Coukos, G., Coutifaris, C., Strauss, J.F., Nathanson, N.: Human immunodeficiency virus type 1 causes productive infection of macrophages in primary placental cell cultures. J Infect Dis 169, 746 (1994)

50. Thaler, M.M., Park, C.K., Landers, D.V., Wara, D.W., Houghton, M., Veereman-Wauters, G., Sweet, R.L., Han, J.H.: Vertical transmission of hepatitis C virus. Lancet 338, 17 (1991)

51. Hershow, R.C., Riester, K.A., Lew, J., Quinn, T.C., Mofenson, L.M., Davenny, K., Landesman, S., Cotton, D., Hanson, I.C., Hillyer, G.V., Tang, H.B., Thomas, D.L.: Increased vertical transmission of human immunodeficiency virus from hepatitis $\mathrm{C}$ virus-coinfected mothers. Women and Infants Transmission Study. J Infect Dis 176, 414 (1997)

52. Cooper, E.R., Schwartz, T., Brena, A., Regan, A.M., Pelton, S.I.: Cytomegalovirus as a cofactor in transmission and progression of perinatal HIV infection. Pediatr AIDS HIV Infect 3, 302 (1992)

53. Doyle, M., Atkins, J., Rivera-Matos, I.R.: Congenital cytomegalovirus infection in infants infected with human immunodeficiency virus type 1. Pediatr Infect Dis J 15, 1102 (1996)

54. Gideon, K. and Zaharopoulos, P.: Cytomegalovirus endocervicitis diagnosed by cervical smear. Diagn Cytopathol 7, 625 (1991)

55. Sever, J.L., Rakusan, T.A., Ellaurie, M., Frenkel, N., Wyatt, L.S., Campos, J.M., O’Donnell, R.M., Price, M.V.: Coinfection with herpesviruses in young children of HIV-infected women. Pediatr AIDS HIV Infect 6, 75 (1995)

56. Nigro, G., Krzysztofiak, A., Gattinara, G.C., Mango, T., Mazzocco, M., Porcaro, M.A., Provvedi, S., Booth, J.C.: Rapid progression of HIV disease in children with cytomegalovirus DNAemia. AIDS 10, 1127 (1996)

57. Mayaux, M.J., Blanche, S., Rouzioux, C., Le Chenadec, J., Chambrin, V., Firtion, .G., Allemon, M.C., Vilmer, E., Vigneron, N.C., Tricoire, J.: Maternal factors associated with perinatal HIV-1 transmission: the French Cohort Study: 7 years of follow-up observation. The French Pediatric HIV Infection Study Group. J Acquir Immune Defic Syndr Hum Retrovirol 8, 188 (1995)

58. Landesman, S.H., Kalish, L.A., Burns, D.N., Minkoff, H., Fox, H.E., Zorrilla, C., Garcia, P., Fowler, M.G, Mofenson, L., Tuomala, R.: Obstetrical factors and the transmission of human immunodeficiency virus type 1 from mother to child. The Women and Infants Transmission Study. N Engl J Med 334, 1617 (1996)

59. St Louis, M.E., Kamenga, M., Brown, C., Nelson, A.M., Manzila, T., Batter, V., Behets, F., Kabagabo, U., Ryder, R.W., Oxtoby, M.: Risk for perinatal HIV-1 transmission according to maternal immunologic, virologic, and placental factors. JAMA 269, 2853 (1993)

60. Pugatch, D., Sullivan, J.L., Pikora, C.A., Luzuriaga, K.: Delayed generation of antibodies mediating human immunodeficiency virus type 1-specific antibody-dependent cellular cytotoxicity in vertically infected infants. WITS Study Group. Women and Infants Transmission Study. J Infect Dis 176, 643 (1997) 
61. Rowland-Jones, S.L., Nixon, D.F., Aldhous, M.C., Gotch, F., Ariyoshi, K., Hallam, N., Kroll, J.S., Froebel, K., McMichael, A.: HIV-specific cytotoxic T-cell activity in an HIV-exposed but uninfected infant. Lancet 341, 860 (1993) 